been obtained sufficiently perfect to decide the question. Dr. Riley, however, informs me that the study of a specimen bred, in 1873 , from the blossom of the buckeye, which specimen he finds specifically identical with mine, renders it certain that the insect is not Proteoteras aesculanum.

Dr. Riley has very kindly allowed me to see his notes on, and figures of $P$. aesculanum. which show several points in which that species markedly differs from the species which I reared. These points are as follows :-

1. The larva here described bores the leaf-stalk of the buckeye and only once have $I$ found a specimen in the terminal twig. $P$. aescularum bores the terminal twig as well as the leaf-stalk.

2. $P$. aesculanum bores the terminal twigs of maple (Acer dasycarpum). I have never seen a specimen of the insect here described on a maple nor have I seen a maple twig or leaf showing indications of its presence.

3. P. aesculanum often forms a swell ing or pseudogall on the stem. The species here alluded to never forms a gall.

4. $P$. aesculanum lives in the gall apparently through almost its whole larval stage. The insect here described, however, quits the leaf-stalk at the end of two or three days and lives in a rolled-up leaf.

5. P. aesculanum bores the stem to a depth of from 13 to $50 \mathrm{~mm}$. The insect here alluded to seldom or never exceeds $13 \mathrm{~mm}$. in its boring.

I may add here a fow words from a recent letter from Dr. Riley. He writes :

"You are safe in changing the determination of your species, for it certainly is not Sericoris instrutana, Clem. You are safe in saying the species is close to $P$. caesculana but nevertheless different, not only in structure and in some of the details of its markings but more particularly in having shorter and more acuminate frontwings. But it is impossible to characterize it either generically or specifically until you get absolutely perfect specimens."

In conclusion I must express my indebtedness to Prof. Fernald and Dr. Riley for the trouble they have taken and the help they have given me. It is only right, also, to add, as an excuse for the imperfect state of this paper, that the doubt concerning the identity of the insect did not arise until the greater part of the paper was in type. This doubt cannot be removed until the brood for 1883 is obtained. In the meanwhile Prof. Fernald has referred the insect, provisionally, to the genus Steganoptycha, Stephens (1834), under the name $S$. claypoleana.

\title{
NOTES ON SPHINGIDAE.
}

BY LAFAYETTE WASHINGTON GOODELL, AMHERST, MASS.

Deilephila lineata is the most common of all the sphingidae here. I have never found the larvae on anything but purslane, Portulaca oleracea, one of the worst of our weeds, and on the cultivated species, $P$. grandiflora; and on these they are found, in all stages of growth, from June to
November. I have seen the half-grown larvae crawling about on the ground as late as 10 Nov, in search of their foodplant which had been destroyed by early frosts. It is not uncommon to see the moths on wing in midday, and often in the full sunshine. The moths are particularly 
fond of the petunia and verbena, and so abundant are they this month (Sept.) that hundreds of them can be seen in an evening hovering over fields of these flowers. The moths from the winter chrysalids first appear early in June, and those from the first brood of larvae early in August.

Scarcely less abundant than $D$. lineata is Dolba hylaeus which occurs from June to September. Next in abundance comes Sphinx gordius, from May to September. S. kalmiae is common from the first part of June to August, and $S$. drupiferarum through June. $S$. eremitus is common from the middle of June to the middle of August. Darapsa choerilus is common from the middle of June to the middle of July. Philampelus achemon and P. satellitia are rather common from the latter part of June to August. Macrosila quinquemaculata is very common from June to September, but $M$. carolina is rather rare. The same remark will apply to Sphinx chersis. The larvae of Ceratomia amyntor feed on the elm (Ulmus) and on the white birch (Betula alba), but are not common.
Our most common $S$ merinthus is $S$. excaecatus, occuring in July and August. A female taken 15 July and confined in a box deposited 331 eggs from 15 to 20 July, about 30 being laid each evening at dusk and the same number in the morning. This was done quite regularly, no eggs being laid at any other time. The eggs are cylindrical, flattened, $2.5 \mathrm{~mm}$. in diameter, and grass-green in color. The larvae began to appear 22 July and all were hatched by $28 \mathrm{July}$. The young larvae measure 4.7 to $5 \mathrm{~mm}$. in length, and are yellowish green with a darker dorsal line. Head pale green, and twice as wide as the body. Caudal horn long, dull red.

Among the rarest of our sphingidae, of which I have taken but one or two specimens each in nine years of collecting, are Smerinthus modestus (22 June and 20 July), S. geminatus (3 Aug.), Sphinx luscitiosa (20 June), Thyreus abbotii (in May), Deilephila chamaenerii (2 June), Choerocampa tersa (15 July), Darapsa versicolor (8 July), Ellema harrisii (2 June).

Amherst, 13 Sept. 1882.
Mumiy of a Wasp.-In Maspero and Brugsch's work "La trouvaille de Deir-elBahari" (1881) is given, according to a note presented by M. Van Segvelt in the July meeting of the Société entomologique de Belgique, a notice of a wasp found preserved in the coffin of Amenophis I, the illustrious king of Egypt. The wasp, attracted probably by the flowers with which the mummy of the king was wrapped previous to interment, had entered the coffin and thus furnished us probably the only specimen of a mummy of a wasp.

De Rhoné, in his "Résumé chronologique de l'histoire d'Egypte," places the accession of Thoutmes I, the successor of Amenophis I, to the throne in $1668 \mathrm{~B}$. C. This insect therefore died 3550 years ago, and is probably the only insect of which the date of death was of such remote antiquity and is so certainly recorded. The name of the species is not given. 

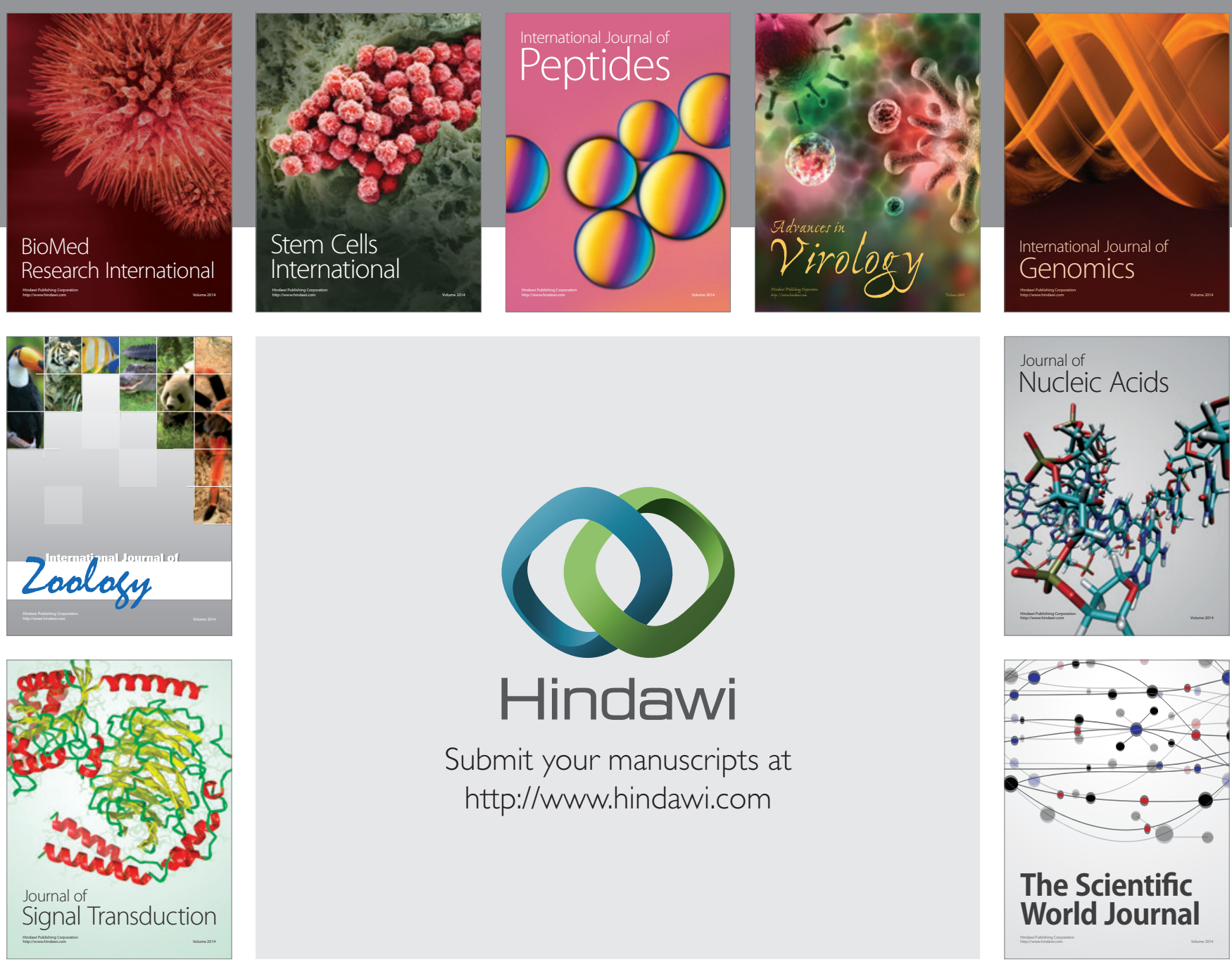

Submit your manuscripts at

http://www.hindawi.com
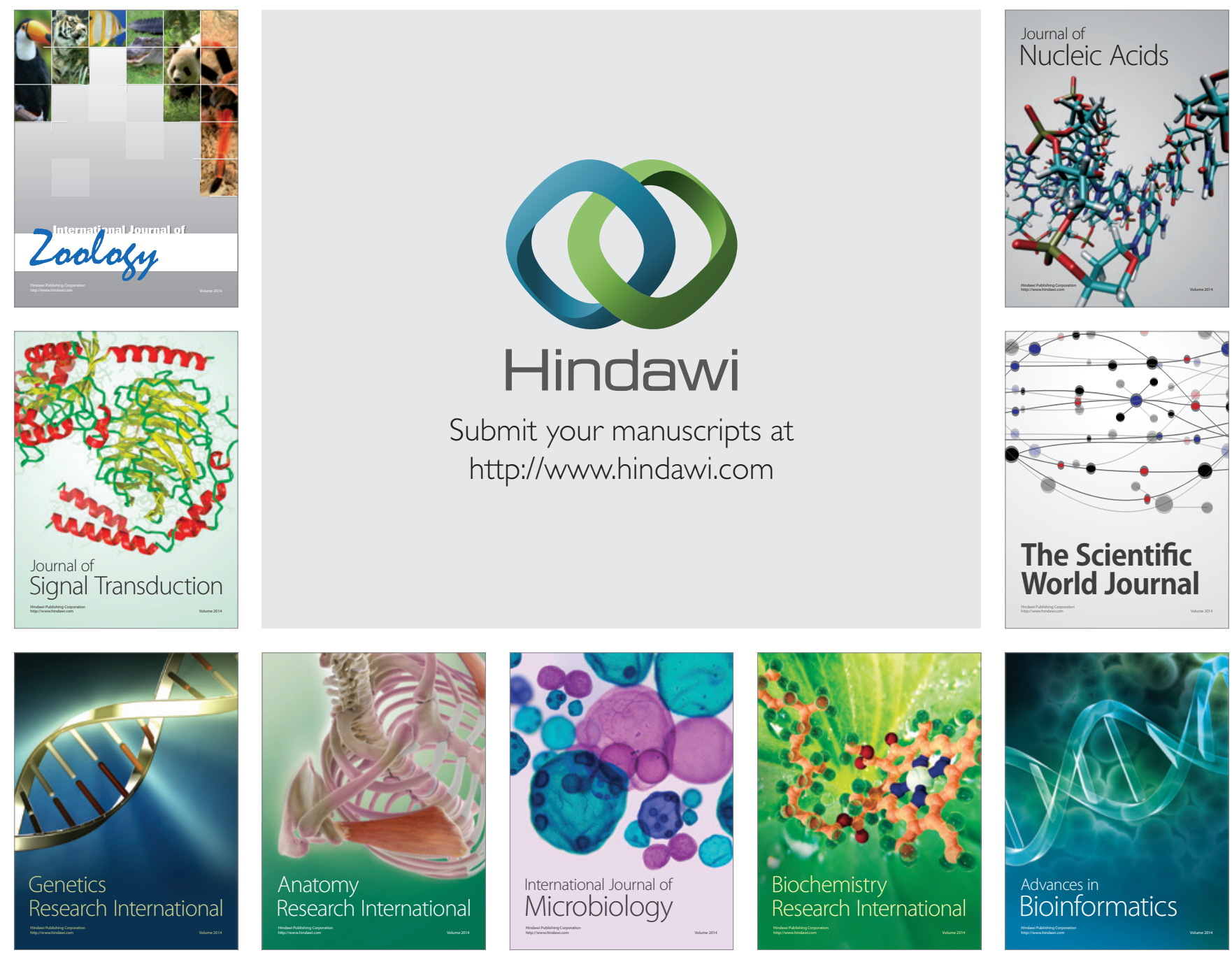

The Scientific World Journal
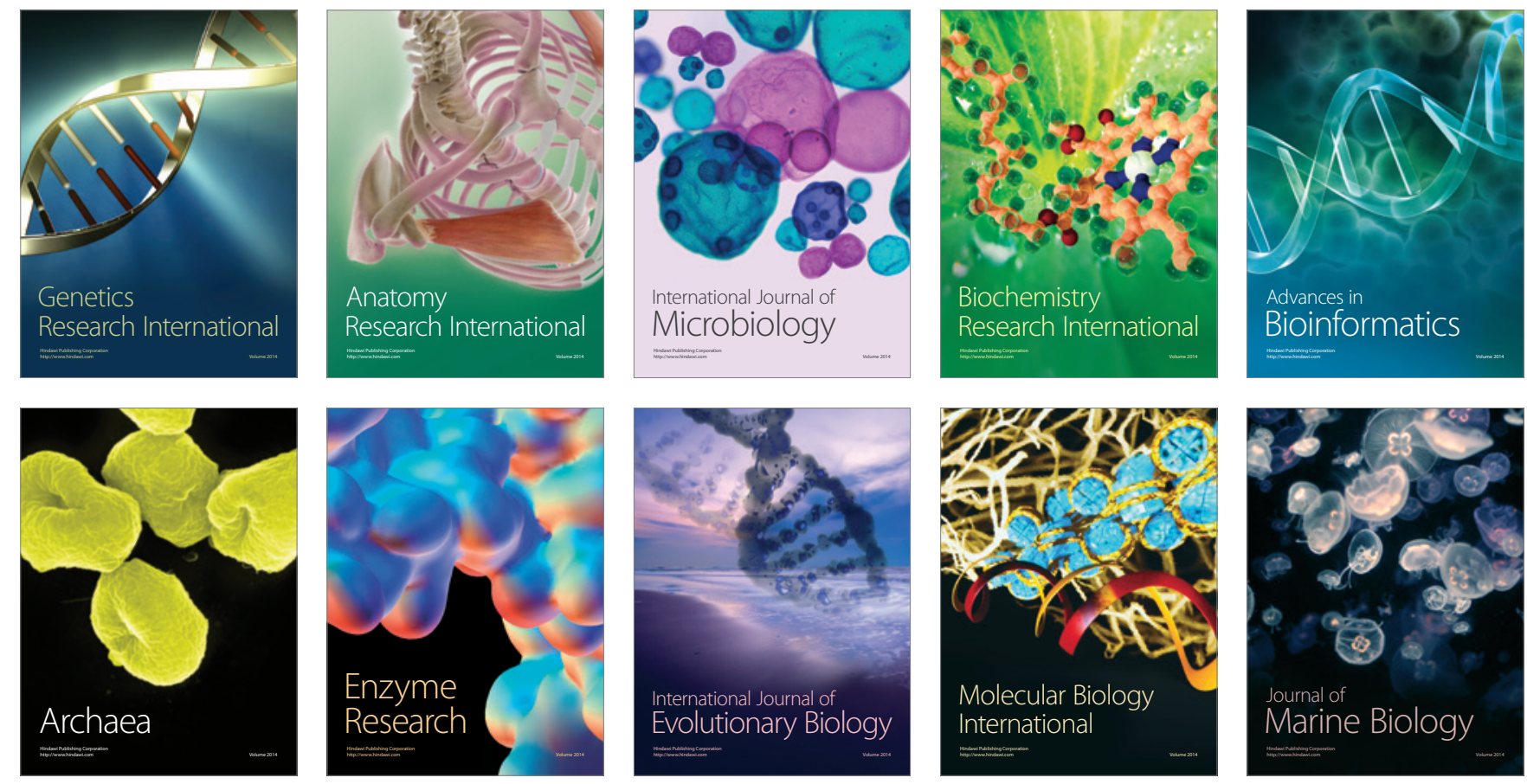